\title{
Isolated Renal Metastasis from Neuroendocrine Tumor: How Rare is Rare? A Case Report and Review of the Literature
} Nöroendokrin Tümörün Izole Renal Metastazı:Seyrek Ne Kadar Seyrektir?
Bir Olgu Sunumu ve Literatür Derlemesi

\author{
Mohga Ali, Irma Lengu, Santhi Ganesan
}

Case Western Reserve University Faculty of Medicine, Metro Health Medical Center, Department of Pathology, Cleveland, USA

\begin{abstract}
Neuroendocrine tumors (NETs) are epithelial neoplasms arising from neuroendocrine cells that are widely distributed throughout the body. The kidney is a rare site for primary NETs and is even rarer as a metastatic site. We report an extremely rare case of a 58-year-old female with metastatic renal NET from a rectal primary without prior or concurrent liver metastasis. Diagnosis of NET of kidney can be challenging due to its rarity. Use of appropriate immunohistochemical markers and awareness of occurrence of these rare lesions in the kidney will enhance the diagnostic accuracy.
\end{abstract}

\section{Keywords}

Neuroendocrine tumors, metastatic neuroendocrine tumors, metastatic renal neuroendocrine tumor

\section{ÖZ}

Multil Nöroendokrin tümörler (NET) vücutta yüksek oranda yaygın olan nöroendokrin hücrelerden meydana gelen epitelyum neoplazmalardır. Böbrek primer NET'ler için nadir bir yerleşim yeridir ve metastaz yeri olarak bile nadirdir. Bu olgu sunumunda bir rektal primerden kaynaklanan metastatik renal NET olan ve geçmiş veya eş zamanlı karaciğer metastazı bulunmayan oldukça nadir 58 yaşında kadın bir olguyu sunduk. Böbrek NET'in tanısı seyrek görülmesinden dolayı oldukça zor olabilir. Uygun immüno-histo-kimyasalların kullanımı ve bu böbrekte seyrek lezyonların oluşabileceğinin farkında olunması tanının doğruluğunu arttıracaktır.

Anahtar Kelimeler

Nöroendokrin tümörler, metastatik nöroendokrin tümörler, metastatik renal nöroendokrin tümörler

\section{Introduction}

Neuroendocrine tumors (NETs) are epithelial tumors arising from neuroendocrine cells that are diffusely distributed throughout the body, most commonly in the gastrointestinal tract and the bronchopulmonary system. Primary renal NETs are rare due to the absence of neuroendocrine cells in the renal parenchyma. Metastatic renal NETs are even rarer with only 2 reported cases in the English literature $(1,2)$. We present a very rare case of metastatic renal NET from a rectal primary. To our best knowledge, this is the first reported case of metastatic renal NET from the rectum without liver metastasis.

\section{Case Presantation}

Our patient is a 58-year-old female with a history of pT2N1M0 rectal NET (equivalent to grade 2 using current World health organization classification) in 2009 (Figure 1). She presented with rectal bleeding and she was found to have a rectal polyp. Subsequent biopsy revealed NET that was positive for chromogranin and synaptophysin, requiring an abdominoperineal resection. In 2013, the patient was found to have a solid mass in the lower pole of the left kidney, suspicious for neoplasm on computed tomography (CT) images of the abdomen and pelvis, without evidence of any other masses, especially in the liver. Biopsy of the renal mass showed a grade 2 NET. The patient was then referred to the urology clinic for left laparoscopic nephrectomy.

We received a left kidney weighing 240 grams and measuring $11.0 \times 8.0 \times 3.0 \mathrm{~cm}$. The kidney was bivalved, revealing a lower pole, completely encapsulated firm white lesion, with a hemorrhagic cut surface (Figure 2), measuring $4.0 \times 3.0 \times 3.0 \mathrm{~cm}$, reaching the renal capsule without invading the perinephric fat. Histological examination of the tumor revealed cords and nests of moderately pleomorphic cells with rare mitotic activity, eosinophilic granular cytoplasm and rounded nuclei with stippled chromatin. The nests were separated by scant stroma and multiple dilated blood vessels (Figure 3). The mass was fully encapsulated and surrounded by a compressed renal parenchyma. The tumor cells stained positive for chromogranin, synaptophysin and CD56 and showed up to 18\% proliferation by Ki-67. The histological findings and the immunohistochemical staining results were compared to the primary rectal tumor and were

\section{Correspondence}

Mohga Ali MD, Case Western Reserve University Faculty of Medicine, Metro Health Medical Center, Department of Pathology, Cleveland, USA

Phone: 316-778-5151 E-mail: mali1@metrohealth.oeg Received: 01.09.2015 Accepted: 17.09.2015 
considered similar except for a new CD56 positivity and a higher Ki-67 index indicating a more aggressive behavior. Based on the clinical and pathological findings, a metastatic NET of the kidney was diagnosed.

\section{Discussion}

The neuroendocrine cell system can be divided into cell types that form the glands (parathyroids, adrenal medulla, paraganglia) and others that

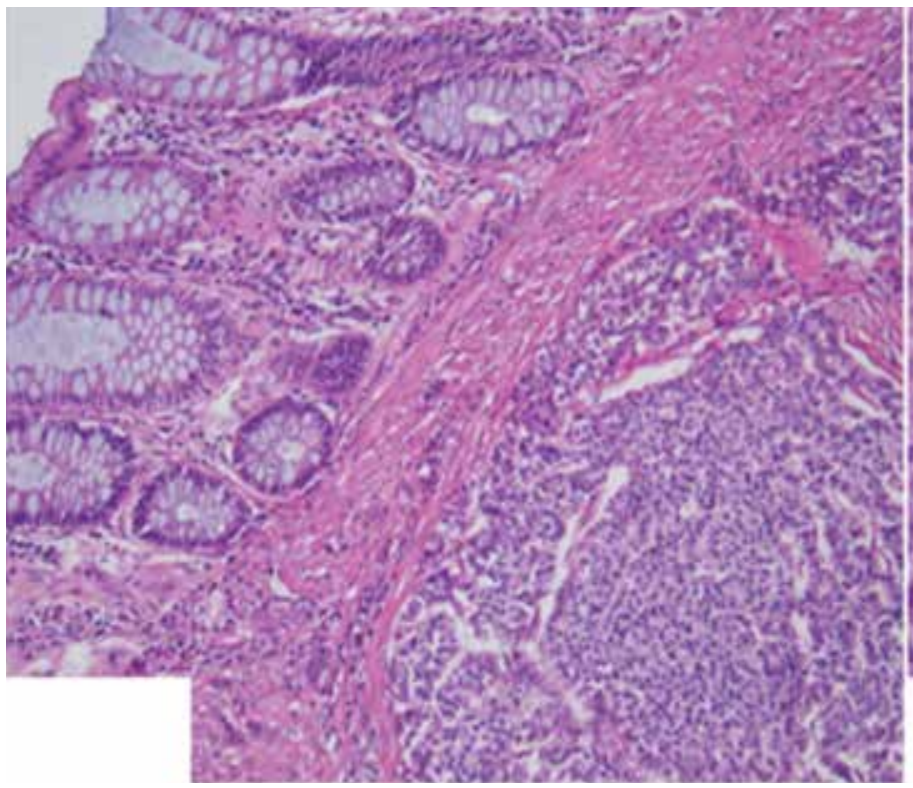

Figure 1. H\&E (20x) of the rectum with submucosal neuroendocrine tumor. The tumor consists of cords and nests of moderately pleomorphic cells with rare mitotic activity, eosinophilic granular cytoplasm, and rounded nuclei with stippled chromatin supported by vascularized stroma
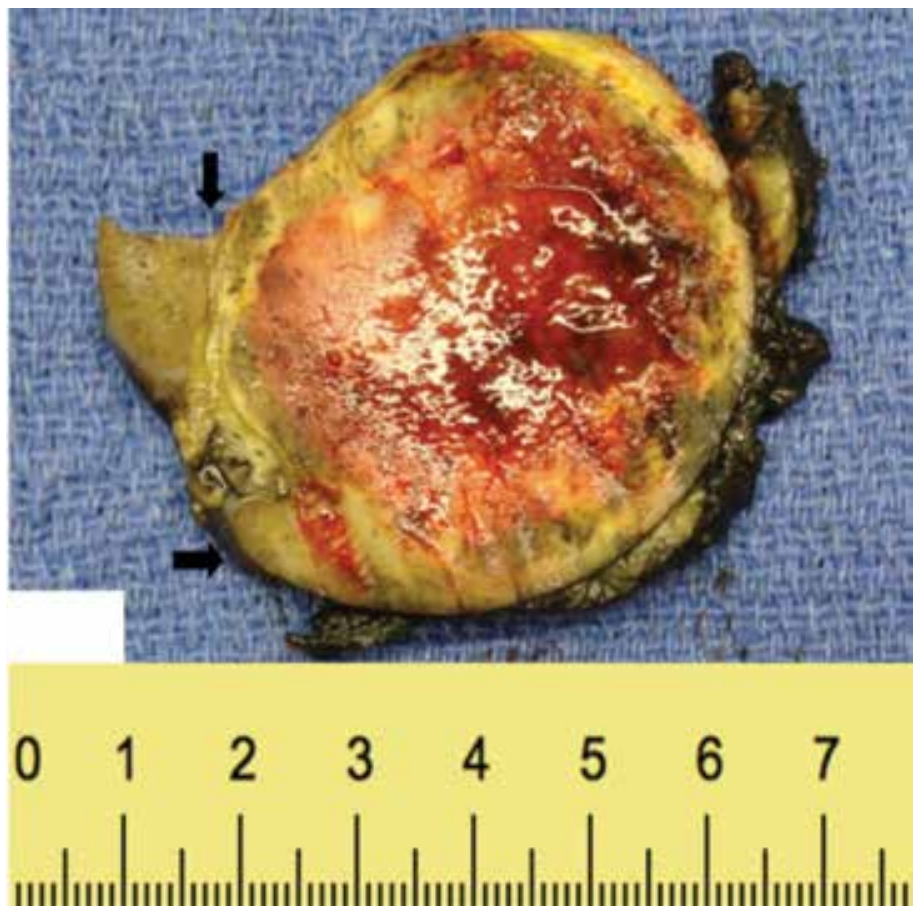

Figure 2. Full cross section of the renal tumor revealing areas of hemorrhage. The tumor is encapsulated and surrounded by a compressed renal parenchyma (arrows) are diffusely distributed, i.e., the disseminated/diffuse neuroendocrine system that populate the skin, thyroid, lung, thymus, pancreas, gastrointestinal tract, biliary tract and the urogenital tract (3).

Epithelial NETs are derived from neuroendocrine cell compartments. Approximately $60 \%$ of carcinoid tumors arise from the intestine, and greater than 25\% arise within the Kultschitzky cells in the respiratory epithelium of the bronchopulmonary system, reflecting the high density of neuroendocrine cells in these organs. NETs arising from other organs occur less frequently and in more obscure sites (4). The liver is considered the predominant site of metastatic spread from NETs, regardless of the primary site. Patients with liver metastases may present with symptoms of carcinoid syndrome (e.g. diarrhea, flushing and wheezing) or symptoms secondary to tumor burden. Neuroendocrine cells have been described in the urinary bladder, urethra, and the renal pelvis, but they are not found within normal renal parenchyma, thus, primary NETs in the kidney are rare and sometimes associated with congenital anomalies, such as horseshoe kidney $(5,6)$ and polycystic kidney disease $(7)$ or in the background of a teratoma (6). Primary NETs can occur in the kidney as a result of metaplastic change, neuroendocrine differentiation of totipotential primitive stem cells, or migration of bronchial or intestinal epithelium to the kidney during development. Metastatic renal NETs are even rarer. To our knowledge; there have been only 2 reported cases of metastatic renal NETs.

The first one by Tal et al. (1); the patient was a 64-year-old woman, status post upper lobectomy of the left lung to remove a bronchial carcinoid tumor. 2 years later, she was admitted for investigating a left neck mass. Abdominal ultrasonography revealed a $3.6 \times 6.7 \mathrm{~cm}$ hyperechoic solid lesion in the right kidney, and multiple hypoechoic lesions occupying both liver lobes. Abdominal CT demonstrated an $8.0 \times 5.0 \mathrm{~cm}$ solid heterogeneous lesion of the right kidney invading the renal pelvis and renal vein but not the inferior vena cava.

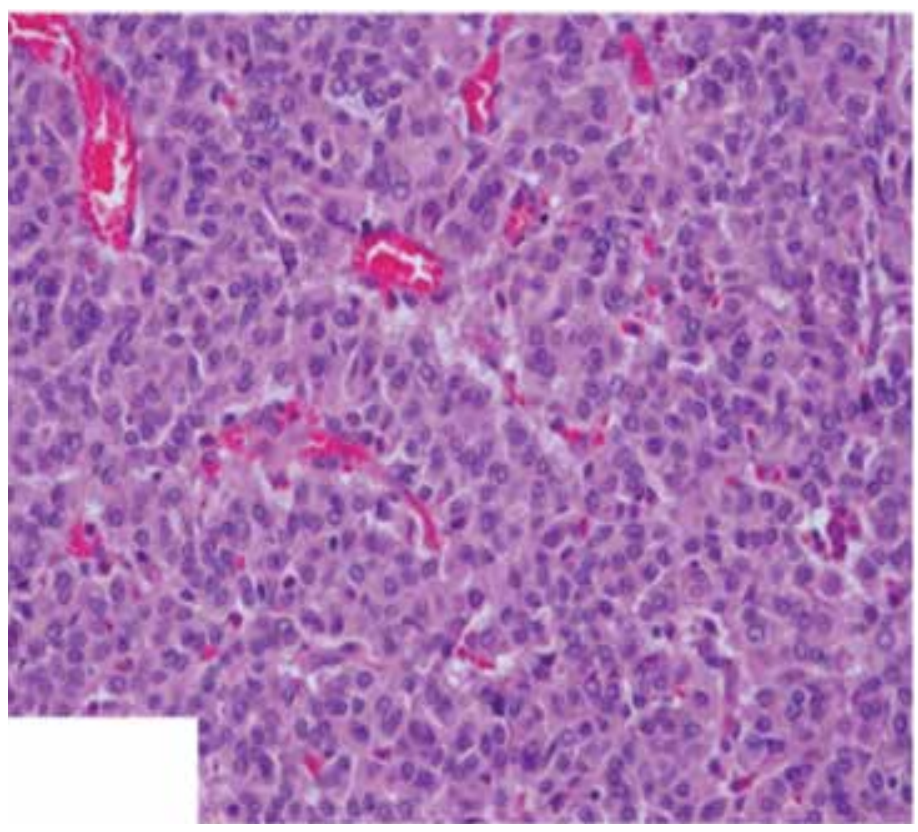

Figure 3. H\&E (40x) of the renal tumor comprised of cords and nests of moderately pleomorphic cells with rare mitotic activity, reminiscent of the rectal neuroendocrine tumor 
Right radical nephrectomy and excision of the hepatic lesion were performed. Microscopically and immunohistochemically, the liver and kidney tumors were consistent with metastatic carcinoid tumor.

The second case by Kato et al. (2); the patient was a 56-year-old man, status post rectal carcinoid resection and resection of liver metastases from the rectal carcinoid, twice. He presented 10 years after the initial presentation during a general check-up with a $3-\mathrm{cm}$ relatively welldefined mass in the lower pole of the left kidney on ultrasonography, and the interior of the mass was low echoic, unclear of margin, and hypovascular. Contrast-enhanced abdominal CT demonstrated a poorly enhanced, well-defined mass at the above-mentioned site in both the arterial and venous phases. A left nephrectomy was performed and histological examination of the renal mass was consistent with those of hematoxylin and eosin staining of specimens of the rectum and liver. As such, a metastatic renal carcinoid was diagnosed.

Our case is unique as the patient presented with a renal mass after initial resection without local recurrence or metastasis to other sites (e.g. liver), in the interim period of 4 years. This clinical course can cause a great diagnostic challenge to the urologist and pathologist as an incidental primary renal neoplasm will be a more likely clinical consideration. Furthermore, metastatic tumors to the kidney are much less common as opposed to primary renal neoplasms.

Due to the rarity of metastatic renal NETs, especially without liver metastasis, a high index of suspicion and thorough proper comparative histologic examination of both the primary tumor and the metastasis will aid in arriving at a correct diagnosis.

\section{Ethics}

Informed Consent: Informed consent was obtained from the participant. Peer-review: Internal peer-reviewed.

\section{Authorship Contributions}

Surgical and Medical Practices: Irma Lengu (urological surgery), Concept: Mohga Ali, Irma Lengu, Santhi Ganesan, Design: Mohga Ali, Data Collection or Processing: Mohga Ali, Analysis or Interpretation: Mohga Ali, Santhi Ganesan, Literature Search: Mohga Ali, Writing: Mohga Ali. Conflict of Interest: No conflict of interest was declared by the authors. Financial Disclosure: The authors declared that this study has received no financial support.

\section{References}

1. Tal R, Lask DM, Livne PM. Metastatic renal carcinoid: case report and review of the literature. Urology 2003;61:838.

2. Kato Y, Nakamura K, Yamada Y, Nishikawa G, Yoshizawa T, Zennnami K, Katsuda R, Tobiume M, Aoki S, Taki T, Honda N. A rare case of metastatic renal carcinoid. BMC Urol 2010;10:22.

3. Klöppel G. Tumour biology and histopathology of neuroendocrine tumours. Best Pract Res Clin Endocrinol Metab 2007;21:15-31.

4. Modlin IM, Lye KD, Kidd M. A 5-decade analysis of 13,715 carcinoid tumors. Cancer. 2003;97:934-959.

5. Hansel DE, Epstein JI, Berbescu E, Fine SW, Young RH, Cheville JC. Renal carcinoid tumor: a Clinicopathologic Study of 21 cases. Am J Surg Pathol 2007;31:1539-1544

6. Shibata R, Okita H, Shimoda M, Asakura H, Murai M, Sakamoto M, Hata J. Primary carcinoid tumor in a polycystic kidney. Pathol Int 2003;53:317322.

7. Sun $K$, You $Q$, Zhao M, Yao $H$, Xiang $H$, Wang L. Concurrent primary carcinoid tumor arising within mature teratoma and clear cell renal cell carcinoma in the horseshoe kidney: report of a rare case and review of the literature. Int J Clin Exp Pathol 2013;6:2578-2584. 